\title{
The Traces of Age of Information Technology in Quran \& Hadith
}

$\begin{array}{r}\begin{array}{r}\text { Naimatillah* }^{*} \\ \text { Mr. Sheikh Adnan Ahmed Usmani }\end{array} \\ \hline \hline\end{array}$

\begin{abstract}
The holy book Quran is revealed by Allah Almighty and it is truly the literal word of Allah Almighty several evidences on this claim has been provided in the holy Quran itself with sane reasoning not only this but Allah Almighty has challenged in the holy Quran all the creations that if anyone claims that this holy book Quran is not the literal word of Allah Almighty or if someone thinks that it has been fabricated then why don't those people try to bring something like Quran. It has been more than fourteen hundred years that challenge has remain unbeaten and during all those years nobody has ever come up with such a perfect book which tells you all about the entire system of the universe and in fact beyond the system of universe. This challenge by Allah Almighty in the holy Quran has made everyone helpless, even in the modern age of information technology where access to any sort of information is just few clicks away. This actually is the miracle of the Holy prophet (peace be upon him) till end of times and since the holy prophet (peace be upon him) is the final prophet of Allah therefore the holy book Quran have all the knowledge of everything from past present and the future. The holy Quran itself claims that it has all the knowledge that has been ever existed there this research paper will find the traces of age of information technology in Quran and Hadith.
\end{abstract}

Keywords: technology, science, innovation, Islam, development

\section{Introduction}

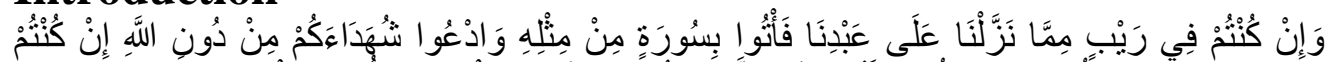

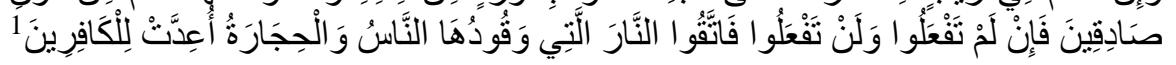

\footnotetext{
* Mr. Naimatillah Research Scholar, University of Karachi, Karachi

${ }^{* *}$ Mr. Sheikh Adnan Ahmed Usmani Research Scholar, University of Karachi, Karachi
} 
And if you are in doubt about what We have sent down upon Our Servant [Muhammad (peace be upon him)], then produce a surah the like thereof and call upon your witnesses other than Allah, if you should be truthful. But if you do not - and you will never be able to - then fear the Fire, whose fuel is men and stones, prepared for the disbelievers. ${ }^{2}$

In the above ayah Allah Almighty has informed that you will never be able to bring anything like the Quran not even like its smallest ayah, either you try it alone or you gather the entire world to help you doing this. This challenge was given by Allah Almighty in the holy Quran almost fourteen and a half hundred years ago and the history has proven that there is no doubt in its truth. There has been so many attempts from the nonbelievers in different times throughout the history but they have always failed to bring anything like the holy Quran. Now the question rises here that why is it impossible to bring something like the smallest single ayah of Quran? Even if the entire universe help each other to do something like this.

The interpreters of the holy Quran have given answer to this question and they "وجوه as "اعجاز" قر آن , the reasons of inimitability or miraculousness of Quran, given as under:

1. Conciseness is one of those reasons, the statements in the holy Quran are so compact and meaningful that no other book can match its standard of conciseness and at the same time "طوالت protractedness or prolonging of فuran has been unmatched it has got such a highest level of concinnity " فصاحت " that no one can ever imitate any ayah. It tells a story one place with preciseness and then the same story has been discussed in details in another part of Quran yet there is no contradiction found between them.

2. Despite of being in Arabic language the holy Quran has its special status in Arabic literature indeed surely the highest standard for Arabic. The nonbelievers in the time of rise of Islam used to confess this that we have never heard anything ever in Arabic language.

3. The matters and stories of the previous nations mention in the holy Quran have been proven right in the human history, for example when occurrence of 
mairaj took place the holy prophet (peace be upon him) was asked about the Aqsa mosque and those who asked the question were stunned by the answer of the holy prophet (peace be upon him) because he never to that place before but told them the entire details of the Aqsa mosque, and there are several other examples.

4. The holy Quran not only told us about the past but also the future events, for example the Quran before war between Jews and Christians told that Christians will win the war in Surah $\mathrm{Al} \mathrm{rum}{ }^{3}$. And this challenge itself as discussed earlier is for all times till the occurrence of the day of judgment.

In this article we will be going through the fourth reason which is related to the future prophecies of Quran about the age of information technology and inventions invented is this age.

In Arabic language the word " اعجزه " is basically derived from the word " معجز " and it is used of any event that occurs through the prophets that is not explicable by nature or any scientific laws and is therefore attributed to divine agency.

Now If something like that occurs through the prophets before their announcement of prophethood then it is called " ارباص", and when something like this occurs after the declaration of their prophethood then its called " معزيه" which is called a miracle in English and if anything like that occurs through a person who is a self-proclaimed false prophethood then it's called " استدر اج and if such thing occurred through magician then it's called a magic, and if such thing happened through a sufi, saint or a pious Muslim person then it's called " (

So actually we will be discussing the اعجاز of the holy Quran about future events precisely the prophecies regarding the age of information technology. Now that we clearly understand the word اعجاز we will move to the term information technology.

It is defined as:

All those technology which are related to information systems and that is an integrated set of components for collecting, storing, and processing data and for providing information, knowledge and digital products comes under the umbrella of information technology $y^{5}$. 
Specifically, we have two types of information available right or true and wrong or false, regarding both there are prophecies of the holy prophet (peace be upon him). Basically the truth or true information has three types:

1. About beliefs ( اعتقادات)

2. About practices (اعمال)

3. About sayings ( اعمال)

The true information regarding beliefs is called "حق", the one regarding practices is called " صو اب", and the one regarding sayings is called " صدق", similarly false or wrong information has also three basic types:

The wrong or false information regarding beliefs is called "باطل "

The wrong or false information regarding practices is called "خطاء"

6 " كذب " The wrong or false information regarding sayings is called

So all the information shared in through information technology belong to one of these types.

Maulana Abul Faiz Ahmed bin Muhammad Al-Ghamari Al-Husainni (1971) has written the facts and figures about the development of inventions and has tried to find clues of those inventions in Quran and Hadith given as under:

\section{Transportation and machines in the holy Quran}

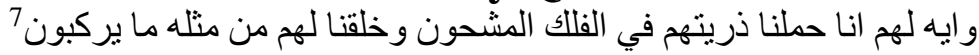

The above ayah enlightens that Allah Almighty has created ships for transportation and traveling and has also created other things which are used for traveling on land, now If we see Allah in this ayah has hinted towards another source of traveling and transportation therefor all the machineries and technology used for transportation comes under this ayah, the word " means that there would a thing that will be big like ships but it will operate on land. Hazrat Abdullah bin Abbas (may Allah be pleased with him) interprets this ayah as:

$$
\text { وخلقنا لهم سفنا امثنال تللك السفن يركبونها8 }
$$

So Allah is has indicated that there are more things like ships which will be used for transportation. In another ayah Allah says: واذا العشار عطلت 9

The word " عشّار" is used for the female camels which are on the $10^{\text {th }}$ month of their conceiving, so Allah in the above ayah is saying that the female camels will be abandoned and won't be used for traveling, because at that time camels were used for transportation and traveling so the Quran says that there will be 
time that using of camels for transportation will be abandoned and there will be other things for doing this. Obviously during the revelation of Quran there was no concept of such inventions nobody could ever thought about modern inventions but the Quran has told this hundreds of years ago.

In another ayah Allah says:

و الخيل و البغال و الحمير لتركبو ها وزينه ويخلق مالا تعلمون 10 In the above ayah Allah has said that horses, mules and donkeys are created by Allah for you on which you can travel and ride them and after that Allah says that Allah will create such things in the future which you will use for riding and you don't know then yet. This ayah clearly indicates that invention of traveling technologies that has been invented so many years after the revelation of this ayah.

\section{Indications about the Inventions in Hadith:}

The holy prophet (peace be upon him) said:

$$
\text { لا تقوم الساعت حتى يتقارب الزمان و يتقارب الاسواق و يطوى الارض111 }
$$

The Day of Judgment will not occur until the time comes closer and the cities come closer and the land being folded.

The above hadith indicates that there will be things through which the distance will be lessened. Today we travel to other continents just in few hours through airplanes and this has got the cities closer to each other. Once the holy prophet (peace be upon him) was asked by his companion that what will be the speed of Dajjal? The holy prophet (peace be upon him) replied that:

His speed will be like the rain which is followed by wind.

$$
\text { كالغيث استدبرته الريح }
$$

This hadith is also indicating towards something very speedy which is definitely an airplane, so maybe Dajjal would use airplanes because the word rain followed by wind is indicating towards planes.

In another Hadith the holy prophet (peace be upon him) said:

$$
\text { حتى يبلغ التاجر بين الافقين فلا يجد ربحا13 }
$$

(The Day of Judgment will not come) before the traders reach the sky and will not get its benefits. 
Now this makes it clearer that there will be such technology that would take people to the skies and people will get its benefits as well, indeed these are nothing but airplanes as we witness a lot of international business exhibitions taken place in different part of the world where the businessmen from different parts of the world gather for few days and get a huge benefit from such events. Furthermore, there is a ferences of electricity in the Holy Quran, Allah Almighty says in the holy Quran:

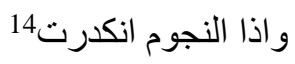

The word "انكدار" is referred to the weakness of the shine or light of luminosity of stars. The companions of the holy prophet (peace be upon him) have narrated about this ayah that this ayah indicates that as the time gets closer to the Day of Judgment the stars will lose their shine or light. This dullness of the shines of stars is due to the heavy usage of electricity lights. Similarly, in the ancient times people used the light of stars to identify the directions to travel but now electricity lights have taken its place. And an evidences for this is that Allah has also discussed the light of sun in the Quran but for that light the word "تكوير" has been used because the electricity makes no effect for the light of sun.

\section{Significance of the Holy Quran}

When the entire world was drowned in the darkness of the illiteracy and when there was no concept of mutual respect and human rights where everyone was always ready to kill each other on small disputes and had forgotten the real concept of God and instead of Allah the people started to worshiping the sun, the moon, the stars and different kinds of idols in fact everyone had made his own God according to his own will, right on that time Allah due to his immense amount of mercy on the people sent the holy prophet (peace be upon him) as the final prophet with the final verdict and code of conduct to the entire creatures till the occurrence of the Day Of judgment who enlightened the world with the light of Tauheed and the same Arabs who were at their worst condition became the leaders of the world. The holy prophet (peace be upon him) during 23 years explained all those things that the mankind needed to know till the Day of Judgment. And just in 23 years the entire situation was changed, everyone got aware of the rights of each other, women got her most respected status ever is human history for the first time and the Arabs abandoned the killing of female child.

The holy prophet (peace be upon him) explained the ummah about the future events as well in the form of Quran and hadith as a complete code of life for 
entire world. It has the answer to every question right from the beginning of world to its end. As a matter of fact, the holy prophet (peace be upon him) not only explained the future events but also warned about the incidents that would take place in future and also taught the ways to come up with those situations and incidents.

It is narrated by Hazrat Ali (may Allah be pleased with him) that the holy prophet (peace be upon him) said:

كتاب الله فيه نبا ما قبلكم وخبر ما بعدكم وحكم ما بينكم 15

The book of Allah i.e. the holy Quran has all the knowledge of past and future and the commands regarding what you have amongst you.

Hence we may say that the present past and the future events and inventions are mentioned in the holy Quran.

Hazrat Abdullah bin Abbas (may Allah be pleased with him) said that:

$$
\text { لو ضاع لي عقال بعير لوجدته في كتاب الله }
$$

Even if I lose my camels rope I can find it in Allah's book (The holy Quran).

Hazrat Ali (may Allah be pleased with him) said that:

لوشئت لاوقرت من تفسير الفاتحه سبعين بعير

If I want to write a tafseer of Surah Al Fatiha (a surah in Quran comprising only 7 ayat) I can load 70 camels with its interpretation.

Means that there is so much knowledge in the holy Quran as Allama Iqbal said:

$$
\text { ساز قرآن را نوابا باقى است } 18
$$

The rhythms concealed in the holy Quran are still to come.

Therefore, it is very essential for the researchers to come towards Quran and hadith because it has been proved throughout the human history that the holy Quran has all the knowledge regarding past present and future.

As Allah Almighty has said:

$$
\text { تبيانا لكل شىء و نزلنا عليك الكثب } 19 .
$$

And we have sent down to you the book that has clarification for everything And this is a miraculous fact of Quran for all times and this strengthens the faith and trust on Allah and his prophet (peace be upon him).

The holy prophet (peace be upon him) said: 


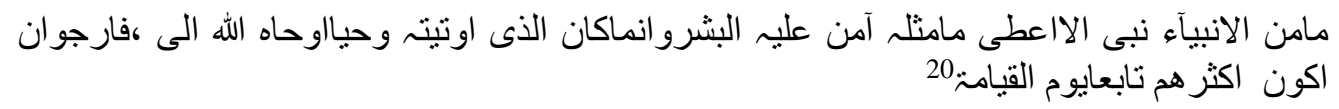

Every prophet has been blessed with a miracle which encourages the people to embrace their preaching and the miracle given to me is what has revealed upon me (the holy Quran) and I hope that in the Day of Judgment my followers will be highest in number.

This hadith also tells us that the former prophets when left the world their miracles remained to their time but the miracle given to the holy prophet (peace be upon him) will remain till the Day of Judgment and that miracle is the holy Quran which always be a source of guidance to the right path for those who seek the right path.

\section{The Age of Info-tech in Hadith}

The holy prophet (peace be upon him) said:

$$
\text { لا تقوم الساعه حتى ترو المور ا عظاما لم تكونو اترونها ولا تحدثون بها|نفسكم }
$$

The Day of Judgment will not occur until you don't see things that had never been thought and seen.

This hadith clearly indicates towards the modern inventions specially the inventions taken place in the age of information technology because all these things were impossible to think and see at that time. Today a person from one part of the world can contact the other person thousand miles away from him in just few seconds, sending emails, making business deals, fighting wars through drones. This was all unthinkable at that time indeed everything related to computer technology at that time was beyond the imaginations.

\section{Voice Typing, Digital Libraries and Internet in Hadith:}

In the book "Ikhtira'at Al Asriah" three ahadith have been discussed, one narrated by Hazrat Abdullah bin masoud in which the holy prophet (peace be upon him) has said that one of the indications of closeness of the Day of Judgment is the emersion of the Qalam. In another hadith narrated by Imam Hasan (may Allah be pleased with him) the holy prophet (peace be upon him) has said that:

$$
\text { لا تقوم الساعه حتى يرفع العلم و يفيض المال ويظهر القلم و تكثر التجاره }
$$

The Day of Judgment will not occur until the knowledge is finished and the commodity and trade gets increased and the Qalam gets emerged. 
So these three things among the other indications of closeness of the Day of Judgment will be witnessed by people. Similarly there is another hadith that mentions that,

$$
\text { ان من اشر اط الساعت ان يفشوا المال وتفشوا التجاره ويظهر القلم }
$$

From the conditions of closeness of the Day of Judgment is that the increase in trade and commodities and emersion of Qalam.

All these three ahadith have enlightened the emersion of the Qalam. The Islamic scholars have different opinions regarding emersion of Qalam. The old school of thought are of the view that the emersion of Qalam means that books and writings and publishing will be increased but the modern school of thought slightly differs in the opinion they argue that writing and publishing had already been increased in the age of Banu Abbas so they think that this emersion of Qalam actually belongs to the modern era. So basically there are two options to define Qalam one is to take the literal (حقيقى) meaning of Qalam and the other option is to take that nonliteral (مجازى) meaning of Qalam.

If the literal meaning is taken, then it is simply the invention of a pen which when was invented long time ago in Egypt known as Qalam Ambos (قلم انبوس). And if the nonliteral meaning is taken then it means the education system itself because it is due to madrasas and schools and universities which actually increased the books and writings as compared to that time. ${ }^{22}$

Maulana Yousuf Ludhyanvi says that abundance of Qalam will occur, ${ }^{23}$ and Maulana Shoaibullah Khan has said that the number of authors will increase and almost everyone would write something like a book of script either being capable of writing or incapable for example the non-Muslims writing books about the core concepts of Islam and other such groups known as orientalists who keep spreading miss concepts and wrong information about Islam and this writing does not mean the writings of Islamic scholars. ${ }^{24}$

What I have preferred is the point of view of old school of thought because the scholars of the old school of thought have discussed two dimensions of this Hadith. One is writing and the other is books will increase. So if we see the first meaning that writing will increase then we will witness that today everyone is busy in writing something either with a pen or with the modern version of pen which is typing in computers, laptops or cellphones but still this is not 
something strange and big enough as all the signs of closeness of the Day of Judgment are always very strange and amazing but another modern way of typing is "voice typing" which is a very wonderful and amazing development of modern times. And if someone limits this meaning to the books then it should be the development of digital libraries and internet which is also a modern invention that amazes everyone because not thousands but billions and trillions of books are there 24/7 for the entire world to read in the internet, and this was really unimaginable and unthinkable at that time when the holy prophet (peace be upon him) had professed it.

\section{Provision of Information Through Text Messages in Hadith:}

The holy prophet (peace be upon him) said that:

ان من اثر اط الساعت ان يفشو المال ويكثر،وتفشو التجاره،ويظهر القلم،ويبيع الرجل البيع فيقول لاحتى

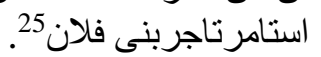

If we see the last portion of this hadith it discusses that the Day of Judgment will not occur until a man does not say to another man that I will not make a trade deal with you until I take the consent or opinion of that man who of that tribe.

Now this style of words indicate that when you say that man it means that you are pointing towards someone which doesn't look something like to be professed as the signs of end of times, so either the person of the other tribe would reside far away from the first person which means despite being far away and the long distance people will be able to communicate in very less time or both people will have different languages but despite of having different languages they would be able to communicate.

Both these things were not possible at that time because trading a commodity needs the decision at that particular moment and taking the opinion of someone who lives far away from the trade point at the time of deal or communicate in other language that is not known to you were impossible but in the modern time through internet as we witness in everyday life that business deals take place so often through WhatsApp, text messages, skype and other such types of communication tools and there are proper official consultation groups in WhatsApp for trading by the experts of particular commodities who guide and charge their clients for their consultancy services and also the amazing google 
translator which has made every language easier to understand and communicate. (و الله اعلم)

\section{Manual \& Electronic Publications:}

In a hadith e Qudsi the holy prophet (peace be upon him) has said that Allah Almighty has says:

ابث العلم فى آخر الزمان حتى يعلمه الرجل و المر اة والعبد والحرو الصغيرو الكبيرفاذافعلت ذلكى بهم

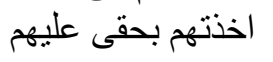

I will spread the knowledge in the final era so that everyone including men and women, elders and kids, the masters and the slaves will have the knowledge and then (after giving them the knowledge) I will hold them (those who despite having the knowledge would not believe Allah) accountable regarding myself.

Now if we see in the modern age the provision of knowledge has two basic ways which were not there at that time when it was professed of prescientific age. One through publishing through printing media and the other through electronic media and internet. Unquantifiable amount of knowledge is being provided from these media and those who are unable to read and write also gain the knowledge through listing radios and watching televisions.

\section{Mentioning the Misuses of Information Technology:}

$$
\text { و ان الدم يسفك بغير حقه و المال يعطي على الكذب }
$$

Unjust blood will be shed and money will be spent to spread false information. In the age of info-tech when we study and observe we easily to the conclusion that there is a lot of false and wrong information being spread in all types of media and a huge amount of investment has been involved in this provision of false information. For example, that advertisement that we see often shows us the qualities that are not actually present in the product being advertised similarly the TV serials and the movies as it is not unknown to anyone that there are movies which earn billions of dollars, the bitter part is that everybody knows that it is all false fake and untrue but still they spend and invest in it. Unfortunately, this the sad reality of the modern age that nobody wants to invest for truth and the false and untruth has got more value in this age where almost everyone knows the truth and information technology has a huge role in provision of such knowledge. 


\section{Conclusion}

All the Muslims believe that the holy Quran is free from any sort of falsehood and mistakes and no other book can be claimed for this attribute and quality Allah Almighty has said that, if this (Quran) would have been from someone else, it would have been full of contradictions. Since Allah Almighty is the creator of everything hence has the perfect word that is Quran. In this research article I have tried to bring ahadith and ayaat of the holy Quran in account to prove the marvel (اعجاز) of Islam regarding the age of information technology. The fact is that there is no information of knowledge that have remained untouched by Islam, it has discussed each and everything from the beginning of this entire system of life till the occurrence of the Day of Judgment and the facts occurring after establishment of the Day of Judgment.

\section{References}

${ }^{1}$ Al Quran, Sura Al baqarah, verse 23-24

${ }^{2}$ http://quran.ksu.edu.sa/translations/english/4.html?a=30

3 Allama Aloosi, “Roohul-ma'ani” v1, p 26, Maktaba Imdadia, Multan

${ }^{4}$ Saadudding Altaftazani, Sharh Aqaid Al Nasafi p 60, Maktabah Rasheedia, Quetta

${ }^{5}$ https://www.britannica.com/topic/information-system

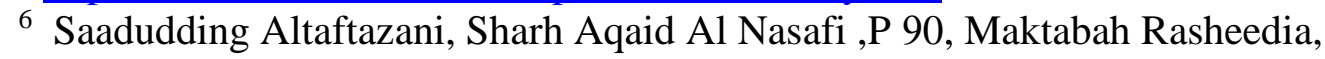
Quetta

${ }^{7}$ Al Quran, Sura Al Yaseen, verse 41-42

${ }^{8}$ Ahmed bin Muhammad bin Alghamari Al Husaini, Al ikhtira'at Al asriah, $p$ 7, dar al-taba'at, Egypt

${ }^{9}$ Al Quran, Surah Al-takweer, verse 4

10 Al Quran, Surah, Nahl, verse 8

${ }^{11}$ Ahmed bin Muhammad bin Alghamari Al Husaini, Al ikhtira'at Al asriah, p. 15, Darul taba'at, Egypt

12 Ibid

13 Ibid, p. 19

${ }^{14}$ Al Quran, Surah Al Takweer, verse 2

${ }^{15}$ Imam Abu Esa Muhammad bin Esa Altarmizi, jamay AL Tarmizi, vol 2, p 573, Maktabah Rehmania, Lahore 
${ }^{16}$ Hafiz Jalaludin Suyuti, Al itqan Fe Uloom Al Quran, vol 3, p 1904, Markaz Al Darasatul Quraniah

${ }^{17}$ Ibid

${ }^{18} \mathrm{http} / / /$ www.allamaiqbal.com/works/poetry/persian/javidnama/text/27.htm

${ }^{19}$ Al Quran, Surah Nahl, verse 89

${ }^{20}$ Muhammad Bin Ismail Al Bukhari, Sahih Al Bukhari, vol 2, p 744, Qadeemi Kutabkhana, Karachi

${ }^{21}$ Naem Bin Hammad, Kitab Al Fitan, p 6, hadith 40

${ }^{22}$ Ahmed bin Muhammad bin Alghamari Al Husaini, Al ikhtira'at Al asriah, $p$ 36

${ }^{23}$ Maulana Yousuf Ludhyanvi, Asr e Hazir Ahadith Nabavi k Aenay Mai, $\mathrm{p}$ 55, Maktabah Ludhyanvi

${ }^{24}$ Muhammad Shoaibullah khan, Hadith e Nabavi Aur Daur e Hazir K Fitnay, Maktabah Maseehul Ummat Deoband, p. 212.

${ }^{25}$ Ahmed bin Muhammad bin Alghamari Al Husaini, Al ikhtira'at Al asriah, p. 19.

${ }^{26}$ Iman Ahmed bin Hanble, Masnad Imam Ahmed. 